\title{
Site-Specific Response Analysis (SSRA) and pairs of ground- motions time-history generation of a site in Jakarta
}

\author{
Sengara I Wayan ${ }^{1,2}$ and Komerdevi Det $^{1 *}$ \\ ${ }^{1,2}$ WSP Engineering Consultant, Bandung \\ ${ }^{2}$ Bandung Institute of Technology, Bandung
}

\begin{abstract}
The purpose of earthquake resistance design of building is to produce a structures that can withstand a certain level of a ground shaking without excessive damage. Careful consideration in the design of structures and facilities to the seismic are implemented by design of ground-motions. Jakarta as the capital city of Indonesia has potential of seismic hazard. Thus, design of high rise buildings in Jakarta requires reliable seismic design criteria for the safety and cost-effectiveness of the construction. Site-specific response analysis with reference to SNI-1726-2012 and generation of pairs of ground-motions with reference to FEMA-10502015 of a proposed high-rise building site in Jakarta has been conducted. Through PSHA, two hazard levels of earthquake have been developed, that is representing 50\% probability of exceedence (PE) in 30 years (43 years earthquake return period) and $2 \% \mathrm{PE}$ in 50 years $(2,475$ years earthquake return period) ground-motions at reference base-rock $\left(\mathrm{S}_{\mathrm{B}}\right)$. In addition, risk-targeted ground-motions (RTGM) defined as $1 \%$ probability of the building collapse in 50 years has been also developed adopting $\beta$-value $=0.65$. Seven pairs of groundmotions time-history have been generated with spectral periods scaling from $0.2-10.0 \mathrm{sec}$ considering seismic sources from Megathrsut, Beniof and Shallow Crustals have been applied to consider the short and long period motions have potential to hit the proposed building with structure period of 7.0 second.
\end{abstract}

\section{Introduction}

Basically, local site condition represented by siteclassification and design response spectra is referred from applicable Building Codes. Seismic design criteria referred directly from the seismic building codes sometime does not accurately represent the seismic hazard of the site, since there is no site-specific hazard and response analysis conducted. Site-specific response analysis (SSRA) with shear wave velocity profile of the site obtained from geophysical test such as: seismic downhole test, microtremor test are considered could provide more accurate recommendations on the seismic design criteria.

The design spectra represent seismic criteria in the design of both foundation system and upper structure of the buildings with certain level of seismic load. That level of shaking is described by a design ground motion, which can be characterized by ground motion parameters. One of the most difficult problem is to define of the boundary between acceptable and excessive damage, and unceretainty in size, time, and of future earthquakes. If very little damage is acceptable, the consequence is a relatively strong level of shaking must be designed for, and the measure required to resist that shaking can be quite expensive, and vise versa. If the greater levels of damage are tolerable, lower design level of shaking may be considered and the resulting design will be less expensive.
Seismic hazard analysis is the critical part of the development of design ground motions involve the quantitative estimation of ground shaking hazards at a particular site. Seismic hazard may be analyzed probabilistically (PSHA), in which uncertanties in earthquake size, location and time occurrence are explicitly considerable or determistically (DSHA), as when a particular earthquake scenario is assumed.

Site specific response analysis (SSRA) need to be conducted to provide seismic hazard assessment at ground surface. This analysis will continue when site specific seismic hazard has been develop at base rock. Probabilsitic seismic hazard analysis has been calculated for two hazard levels of earthquake representing 50\% probability of exceedence (PE) in 30 years (43 years earthquake return period), refered to as SLE, and $2 \% \mathrm{PE}$ in 50 years $(2,475$ years earthquake return period), refered to as MCE, at reference base-rock (SB).

\section{Probabilistisc Seismic Hazard Analysis (PSHA) of Jakarta Site}

The PSHA methodology considers 3-dimensional seismic source zones. Total probability theorem assuming earthquake magnitudes (M), hypocenter distances (r) as continuous independent random variables that affected the intensity (I), in this case PGA or spectral acceleration,

\footnotetext{
${ }^{*}$ Corresponding author: det.komerdevi@wsp-engineering.com
} 
is adopted in this PSHA. This theorem is implicitly implemented in EZ-FRISK computer program [Risk Engineering, Version 7.62, 2011] to be used in the PSHA. The essential components of the PSHA will consist of seismic source zoning, earthquake recurrence, attenuation functions, and logic tree formulation.

\subsection{Seicmic Source Zoning of Java Island}

\subsubsection{Geological Condition}

Based on geological and historical condition seismic source zones of Jakarta predominantly controlled by subduction type source zone which the Australian plate subducting under the Eurasian plate. From hypocenter profile plots (Fig. 2-1) can be seen that the earthquake hypocenter subducts from south to north. it is estimated that Jakarta earthquake with subduction mechanisms is caused by these arc activities.



Fig. 2-1 Cross-section of geological condition corresponds to subduction zone

\subsubsection{Seicmic Data}

Seismicity data within radium $500 \mathrm{~km}$ from the site (Fig. 2-2) has been compiled from re-located Enghdal (19632009). The seismicity data has been analyzed for the main shock (independent) data through distance and timewindow analysis. In addition, Shallow crustal source zones that contribute to Jakarta seismicity consist of Cimandiri, Lembang and Sunda faults.

\subsection{Maximum Magnitude and Slip-Rates}

The maximum magnitude and slip-rate are estimated based on the evaluation of available data and tectonic of the region. The procedure identifies a reasonable maximum magnitude for the given potential seismic source, and its most reasonable slip rate in the current tectonic environment. These values correspond to the report on Development of Seismic Hazard Map of Indonesia for Revision of Map in SNI-03-1726-2002 by Team-9 (2010). For Java and Southern Sumatra Interface (mega-thrust) subduction, the maximum magnitude referred from Team-9 (2010) is $\mathrm{M}_{\max }=8.1$ and 8.5, respectively. However, since there are large uncertainties in this maximum magnitude and the recent earthquakes that has occurred in the Indonesian and Japan subduction mega-thrust that generated $\mathrm{M}_{\max }$ above 9.0, then in this PSHA we consider potential of $\mathrm{M}_{\max }=8.5$ to the Java and Southern Sumatra Interface (mega-thrust) subduction.



Fig. 2-2 Distribution of main-shocks seismicity data around Jakarta

\subsection{Ground Motion Predictive Equation (GMPE)}

New Generation Attenuation (NGA) functions are adopted for shallow crustals seismic sources and shallow background. The NGA is elaborated in Earthquake Spectra, Special issue on the NGA Project (Stewart et al., 2008). The specific GMPEs from NGA that we adopt are those developed by Boore-Atkinson (2008), CampbellBozorgnia (2008), and Chiou-Young (2008). These three NGA GMPEs have been included in EZ-FRISK Version 7.62 that is used for this PSHA. We give equal weight of $33 \%$ for each of this GMPE.

For deep intra-slab (deep background) sources, we adopt Atkinson-Boore (2003) developed from Cascadia Intra-slab. Please note that these GMPEs are valid for ground motions to period limited to 3 seconds.

\section{Result of Seismic Hazard of Jakarta}

\subsection{Peak Baserock acceleration}

The Uniform Hazard Spectrum is created for a given hazard level by enveloping the results of seismic hazard analysis for each period (for a given probability of exceedance). Generally, UHS will be a conservative target spectrum if used for ground motion selection and scaling, especially for large and rare ground motions, unless the structure exhibits only elastic first mode response. This inherent conservatism comes from the fact that the spectral values at each period are not likely to all occur in a single ground motion (Bommer et al., 2000; Naeim and Lew, 1995; Reiter, 1990).

Two hazard levels were calculated, that is representing $50 \%$ probability of exceedence (PE) in 30 years ( 43 years earthquake return period) and $2 \% \mathrm{PE}$ in 50 years $(2,475$ 
years earthquake return period) ground motions at reference base-rock (SB) of project site. Uniform Hazard Spectra (UHS) and de-aggregation for each hazard level were also resulted. Summary of mean Uniform Hazard Spectra (UHS) for these return periods as shown in Error! Reference source not found.

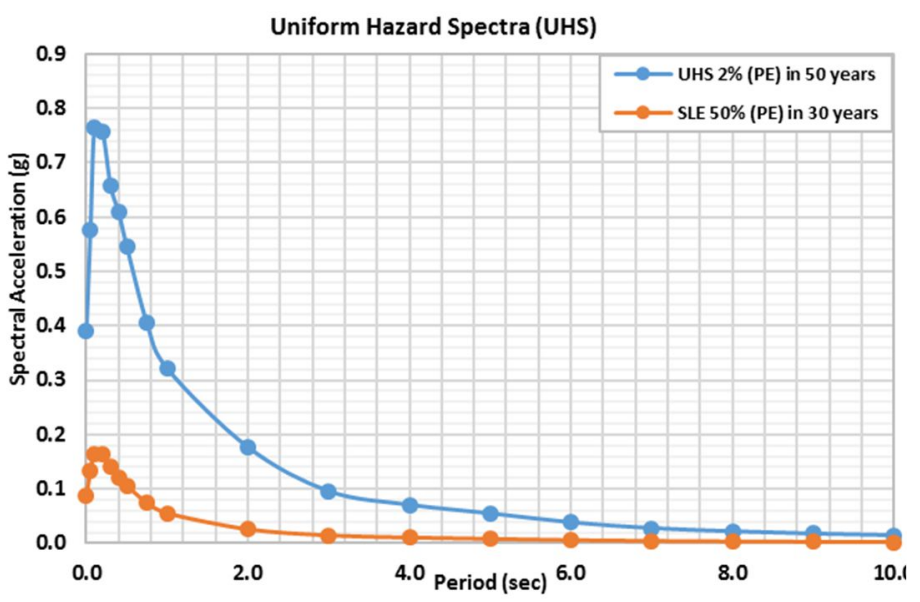

Fig. 3-1 Uniform Hazard Spectra

\subsection{Hazard Curve}

Hazard curves result of seismic hazard analysis are presented that show hazard curves with each seismic source contribution to the seismic hazard for five periods of interest, that are representing of $\mathrm{T}=\mathrm{PBA}, \mathrm{T}=0.2, \mathrm{~T}=1.0$, $\mathrm{T}=2.0, \mathrm{~T}=5.0$ and $\mathrm{T}=10$ seconds. Fig. $3-2$ shows that hazard curve for $\mathrm{T}=5.0$ second that provide total hazard of annual frequency of axceedence and spactral acceleration of Jakarta site.

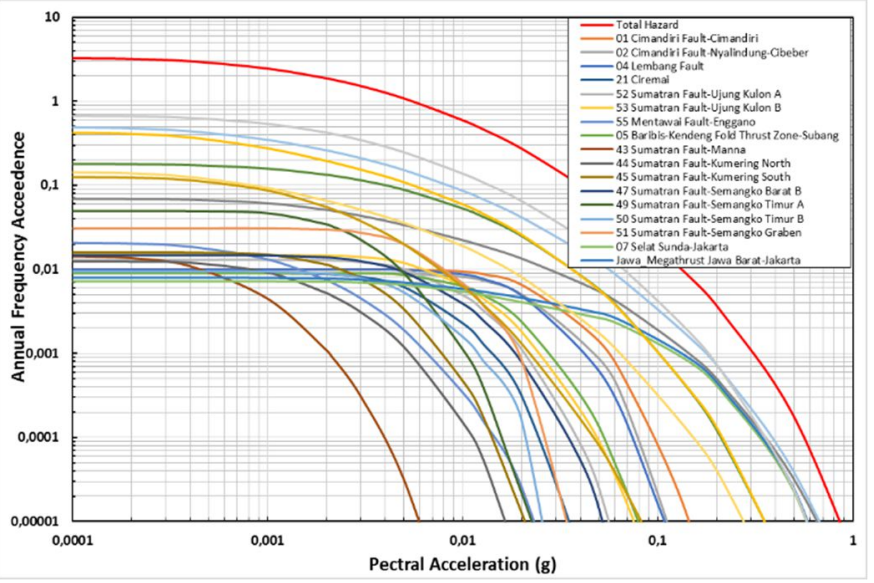

Fig. 3-2 Hazard Curve at $\mathrm{T}=5.0 \mathrm{sec}$

\subsection{Deaggregation Hazard}

De-aggregation as integrated process of the PSHA illustrates the properties of ground motions that meet or exceed a given intensity at a particular location (mathematically, the probability distribution of properties such as earthquake magnitude and distance, conditional on exceedance of some ground motion intensity level).
The height of the bars indicates the percentage contribution to exceedance of a given intensity level from of earthquakes from a particular magnitude and distance (indicated by the coordinates of the horizontal axes) and $\varepsilon$ (indicated by the colour of the bar).

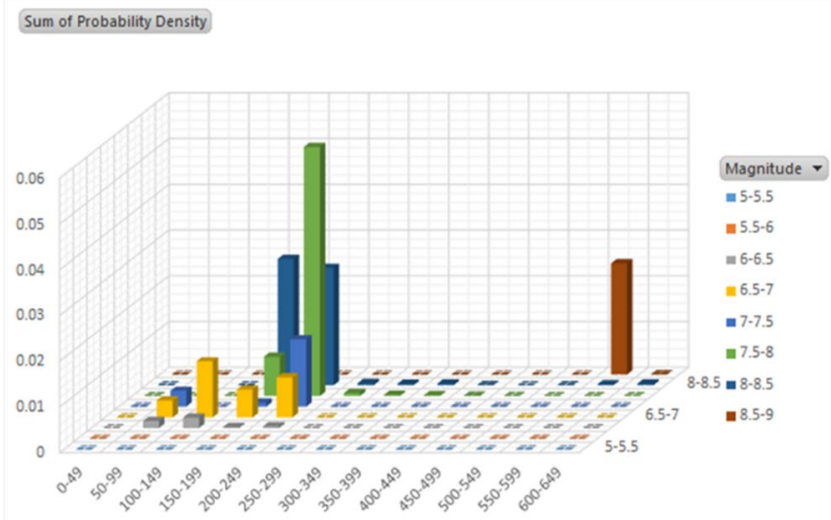

Distance 7

Fig. 3-3 Deaggregation hazard $\mathrm{T}=5.0 \mathrm{sec}, \mathrm{MCE}$

The chart bars (Fig. 3-3) show distribution magnitude and distance that have contribution to the sesimic hazard at $\mathrm{T}=5.0$ second of MCE. For long period of interest $(\mathrm{T}=5.0$ sec), the total hazard is dominated by deep background source (benioff) with magnitude $7-8$ and distance $200-$ $250 \mathrm{~km}$.

In addition, deaggregation chart bars for SLE (Fig. 3-4) shows that dominant hazard contribution is deepbackground source (benioff) with magnitude $7-8$ and distance $100-150 \mathrm{~km}$.



Fig. 3-4 Deaggregation hazard T=5.0 sec, SLE

Mean value of M and R for MCE and SLE are tabulated in Table 3-1 and detail contibution of each source for MCE are presented in Table 3-2.

Table 3-1 Mean $M$ and $R$ of Deaggregation hazard

\begin{tabular}{|c|c|c|c|c|}
\hline \multirow{2}{*}{ Period } & \multicolumn{2}{|c|}{$\mathbf{5 0 \%}$ PE in 30 years } & \multicolumn{2}{c|}{ 2\% PE in 50 years } \\
\cline { 2 - 5 } & $\begin{array}{c}\text { Mean } \\
\text { Magnitude }\end{array}$ & $\begin{array}{c}\text { Mean } \\
\text { Distance }\end{array}$ & $\begin{array}{c}\text { Mean } \\
\text { Magnitude }\end{array}$ & $\begin{array}{c}\text { Mean } \\
\text { Distance }\end{array}$ \\
\hline \hline $5.0 \mathrm{sec}$ & 7.05 & 220 & 7.80 & 247 \\
\hline $10.0 \mathrm{sec}$ & 7.08 & 214 & 7.72 & 230 \\
\hline
\end{tabular}


Table 3-2 Detail contribution $M$ and $\mathrm{R}$ of MCE

\begin{tabular}{|c|c|c|c|c|}
\hline & $\begin{array}{c}\text { Source } \\
\text { Mechanism }\end{array}$ & $\begin{array}{c}\text { Dominant } \\
\text { Source }\end{array}$ & $\begin{array}{c}\text { Magnitud } \\
\text { e }\end{array}$ & $\begin{array}{c}\text { Distance } \\
\text { (km) }\end{array}$ \\
\hline \hline \multirow{7}{*}{$\mathbf{5 . 0 ~ s e c}$} & $\begin{array}{c}\text { Megathrust } \\
\text { (Interplate) }\end{array}$ & $\begin{array}{c}\text { Jawa_Megathr } \\
\text { ust Jawa Barat }\end{array}$ & 8,6 & 151 \\
\cline { 2 - 5 } & $\begin{array}{c}\text { Deep } \\
\text { Background } \\
\text { (Benioff) }\end{array}$ & $\begin{array}{c}\text { Background } \\
100-150 \mathrm{~km}\end{array}$ & 7,2 & 160 \\
\cline { 2 - 5 } & $\begin{array}{c}\text { Shallow } \\
\text { Crustal }\end{array}$ & $\begin{array}{c}\text { Cimandiri } \\
\text { Fault- } \\
\text { Cimandiri }\end{array}$ & 6,6 & 89 \\
\cline { 2 - 5 } & $\begin{array}{c}\text { Shallow } \\
\text { Background }\end{array}$ & $\begin{array}{c}\text { Background } \\
10-20 \text { km }\end{array}$ & 6,3 & 16 \\
\hline \multirow{5}{*}{$\mathbf{1 0 . 0}$} & $\begin{array}{c}\text { Megathrust } \\
\text { (Interplate) }\end{array}$ & $\begin{array}{c}\text { Jawa_Megathr } \\
\text { ust Jawa Barat }\end{array}$ & 8,6 & 150 \\
\cline { 2 - 5 } & $\begin{array}{c}\text { Deep } \\
\text { Background } \\
\text { (Benioff) }\end{array}$ & $\begin{array}{c}\text { Background } \\
100-150 \mathrm{~km}\end{array}$ & 7,2 & 160 \\
\cline { 2 - 5 } & $\begin{array}{c}\text { Shallow } \\
\text { Crustal }\end{array}$ & $\begin{array}{c}\text { Cimandiri } \\
\text { Fault- } \\
\text { Cimandiri }\end{array}$ & 6,6 & 89 \\
\cline { 2 - 5 } & $\begin{array}{c}\text { Shallow } \\
\text { Background }\end{array}$ & $\begin{array}{c}\text { Background } \\
10-20 \mathrm{~km}\end{array}$ & 6,3 & 16 \\
\hline
\end{tabular}

\subsection{Target Spectra}

\subsubsection{Anchored at period $T>3.0 \mathrm{sec}$}

sSince the aforementioned adopted GMPEs for subduction are only valid for periods less than 3 seconds, for periods of interest higher than 3 second, spectral accelerations are estimated using anchor following relationship:

$$
\mathrm{S}_{\mathrm{aT}}=\left(\mathrm{S}_{\mathrm{a} 3.0 \text { secs. }} \times 3.0\right) / \mathrm{T}
$$

where $\mathrm{T}$ is period of interest longer than 3 seconds. The UHS with anchored at period T $>3.0 \mathrm{sec}$

\subsubsection{Directionality Coefficient for maximum Response}

No factor is multiplied to the PGA value. The range of maximum directionality factor between PGA and $0.2 \mathrm{sec}$ is interpolated linearly between $1.0-1.1$, the range of directionality factor between $0.2 \mathrm{sec}$ and $1.0 \mathrm{sec}$ is interpolated linearly between 1.1-1.3, the range of directionality factor for periods above $1.0 \mathrm{sec}$ is taken to be 1.3 . Note that, for $7 \% \mathrm{PE}$ in 75 years spectral values and $10 \%$ in 50 years these factors (1.10 for Ss and 1.30 for $S_{1}-S_{10}$ ) need to be multiplied as well to the spectral values from the geometric mean PSHA.

\subsubsection{Baserock Risk-Targeted Ground-Motion (RTGM)}

New concept in the risk-targeted base seismic design criteria is introduced in ASCE-SEI-7-10 and 2010-PEER Guidelines for Performance-Based Seismic Design of Tall Buildings, that the seismic criteria are not only based on seismic hazard as previously adopted by many building codes, but based on probability of collapse of the buildings. The ground-motions derived from this concept is called risk-targeted ground motion (RTGM). The analysis developed herein is based on $\mathrm{MCE}_{\mathrm{R}}$ defined as $1 \%$ probability of collapse of the building in 50 years,

Since the new criteria is based on RTGM, then $\mathrm{MCE}_{\mathrm{R}}$ need to be derived from MCE seismic hazard and characteristics of the building in the form of its fragility. As the $\mathrm{MCE}_{\mathrm{R}}$ is available, then design spectral values are adopted to be $(2 / 3)$ of the spectral values derived from $\mathrm{MCE}_{\mathrm{R}}$ with reference to its spectral values at various periods.

Calculation of RTGM is done by direct integration method of multiplication of annual frequency of ground motion value $\gamma^{\prime}(a)$ (site-specific hazard curve) and probability of building resistance $(\mathrm{Pf} \mid \mathrm{a})$. Uncertainty in building resistance is generally represented as building fragility. Probability of exceedance of $a^{*}$ is generally formulated by the following equation (McGuire, 2004):

$$
\mathrm{P}\left[\text { damage }>\mathrm{a}^{*}\right] \cong \int_{\mathrm{a}}^{\tilde{\mathrm{P}}} \mathrm{P}\left[\text { damage }>\mathrm{a}^{*} \mid \mathrm{a}\right] * \gamma^{\prime}(\mathrm{a}) \mathrm{da}
$$

where:

$\gamma^{\prime}(\mathrm{a})$ is The annual frequency of events with amplitude a

$\mathrm{P}\left[\right.$ damage $\left.>\mathrm{a}^{*}\right]$ is probability occurred within one year

The equation is cumulative density function (CDF) that further can be replaced with normal distribution using the following equation:

$$
\begin{aligned}
& \mathrm{P}_{\mathrm{F}} \cong \int_{0} \gamma(\mathrm{a}) \frac{\mathrm{dP}_{\mathrm{F} \mid \mathrm{a}}}{\mathrm{da}} \\
& \mathrm{P}_{\mathrm{F} \mid \mathrm{a}}=\int_{0}^{\mathrm{a}} \frac{1}{\mathrm{a} \sqrt{2 \pi \beta}} \exp \left[-\frac{(\ln \mathrm{a}-\overline{\ln \mathrm{y}})^{2}}{2 \beta^{2}}\right] \mathrm{da}
\end{aligned}
$$

where :

$\gamma(\mathrm{a})$ is site-specific hazard curve from PSHA.

$\frac{\mathrm{dP}_{\mathrm{F} \mid \mathrm{a}}}{\mathrm{da}}$ is capacity distribution.

$\overline{\ln y}$ is median of logaritmic capacity $x$ directivty factor, where directivity factor $=1.0$ for PGA, 1.1 for $0.2 \mathrm{sec}$ and 1.3 for $1 \mathrm{sec}$.

$\beta$ is logarithmic's standard deviation.

The $C_{R S}$ and $C_{R 1}$ values have been calculated used integrated hazard spectra combined with fragility building, meanwhile for period $T \geq 1.0$ the $C_{R}$ value taken as $C_{R 1}$, for period of $T \leq 0.2$ the $C_{R}$ value taken as $C_{R S}$, for period of $T$ between $0.2-1.0 \mathrm{sec}$ the value of $C_{R}$ used linear interpolation and for $\mathrm{T}=\mathrm{PGA}$ the the $\mathrm{C}_{\mathrm{R}}$ value taken as 1.0. $\mathrm{MCE}_{\mathrm{R}}$ target spectra are obtained by multiplying MCE with $C_{R}$ values for each period of interest.

\subsection{Conditional Mean Spectrum (CMS)}

The Conditional Mean Spectrum (CMS) is an alternative target spectrum to the Uniform Hazard or MCER spectra and can be used as a target for ground motion selection in performance-based engineering (e.g., Baker, 2006, 2011, Al Atik and Abrahamson 2010). 
Table 3-3 Value of $\mathrm{C}_{\mathrm{RS}}$ and $\mathrm{C}_{\mathrm{R} 1}$

\begin{tabular}{c|c|c|c|c|c|c|}
\hline $\begin{array}{c}\text { Coor } \\
\text { dinate }\end{array}$ & $\begin{array}{c}\text { Period } \\
(\mathbf{s e c})\end{array}$ & $\begin{array}{c}\text { D. } \\
\text { Factor }\end{array}$ & $\begin{array}{c}\boldsymbol{\beta}- \\
\text { value }\end{array}$ & $\begin{array}{c}\text { RTGM } \\
(\mathbf{g})\end{array}$ & $\begin{array}{c}\text { MCE } \\
\mathbf{( g )}\end{array}$ & $\mathbf{C r}$ \\
\hline \hline $\begin{array}{c}\text { long: } \\
106,82 \\
\text { lat: }\end{array}$ & 0,2 & 1,10 & 0,65 & 0,838 & 0,758 & 1,006 \\
$-6,22$ & 1,0 & 1,30 & 0,65 & 0,402 & 0,321 & 0,963 \\
\hline
\end{tabular}

To address the above-mentioned problem with the Uniform Hazard Spectrum as a target for ground motion selection and scaling, the Conditional Mean Spectrum instead conditions the spectrum calculation on a spectral acceleration at a single period, and then computes the mean (or distribution of) spectral acceleration values at other periods. This conditional calculation ensures that the resulting spectrum is reasonably likely to occur, and that ground motions selected to match the spectrum have an appropriate spectral shape consistent with naturally occurring ground motions at the site of interest.

The response spectra for these events scaled to the $\mathrm{T}=0.2 \mathrm{sec}, \mathrm{T}=1.0 \mathrm{sec}, \mathrm{T}=2.0 \mathrm{sec}$, and $\mathrm{T}=5.0 \mathrm{sec}$ value used Conditional Mean Spectrum (CMS) as proposed by Baker et.al. (2011). The CMS describes the mean response spectrum of a ground motion having the magnitude, distance and value that caused occurrence of a target spectral acceleration at some conditioning period. The CMS differs from the Uniform Hazard Spectrum, which envelopes response spectra from multiple magnitudes, distances, and values, and thus does not represent the spectrum of any one ground motion.



Fig. 3-5 Conditional Mean Spectrum for RP 2475 years

\section{Site Specific Response Spectra of Jakarta}

Ground response analyses are used to predict ground surface motions for development of design spectra, to evaluate dynamic stresses and strains and to determine the earthquake-induced forces that can lead to instability of earth and earth-retaining structures.

The propagation of stress waves through the earth to the top of bedrock beneath a aparticular site, and would determine how the ground surface motion is influenced by the soil lie above the bedrock the bedrock. The influence of local soil conditions on the nature of earthquake damage by strong ground motion has been recognizes for many years. The rock-based earthquake motions can be amplified at soil layers and will be cause severe structural damages at ground surface.

\subsection{Shear waves velocity (Vs)}

The problem of ground response analysis then becomes one of determining the response of the soil deposits to the motion of the bedrock immediately beneath it. The soil plays a very important role in determining the characteristics of ground surface motion. The seismic waves travel through $280 \mathrm{~m}$ of soil at Jakarta site determine by combination of NSPT correlation data, microtremor survey and seismic downhole test, for the top 30 meter soil characteristic, it is classified that the soil classification is in the range of Soft Soil $\left(\mathrm{S}_{\mathrm{E}}\right)$ and Medium Soil $\left(\mathrm{S}_{\mathrm{D}}\right)$. The soil profle of shear waves velocity is presented at Fig. 4-1.

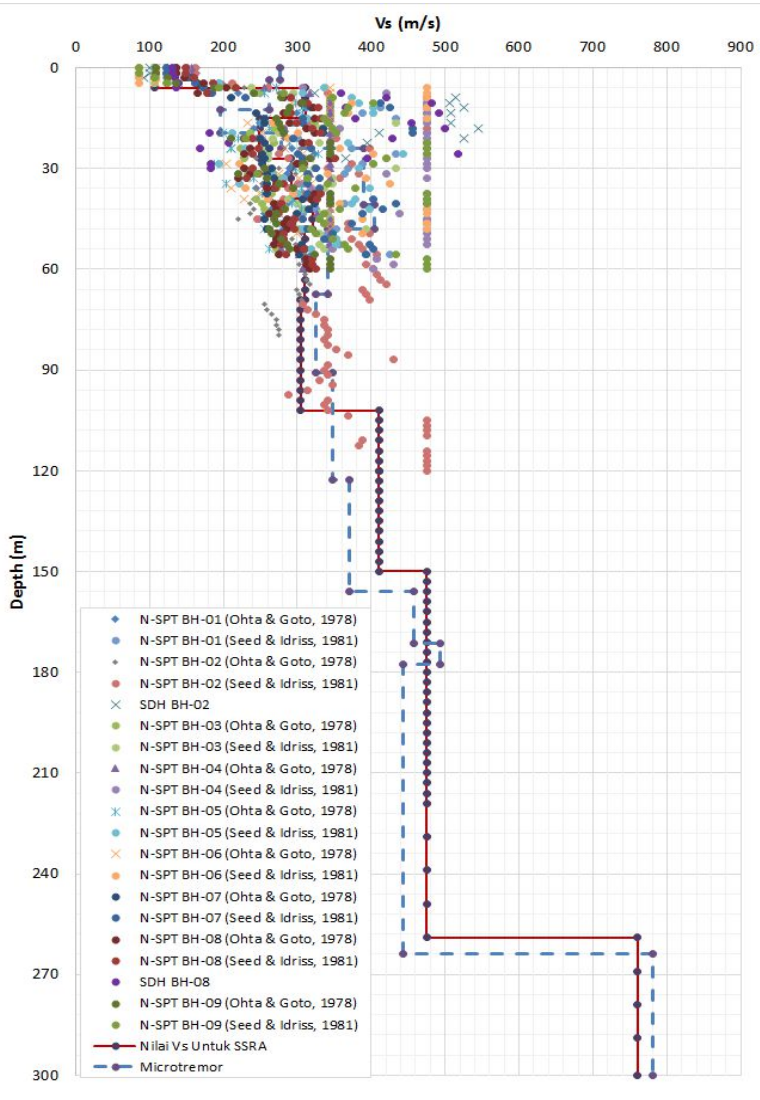

Fig. 4-1 Soil Profile shear waves vcelocity

\subsection{Recommendation on Surface Spectra}

Local site effect have to be considered in earthquake resistant design and must be accounted for on a case by case basis. This condition usually develop of one or more design ground motion that reflect certain levels of strong motion amplitude, frequency content, and duration that a structure or facility at a particular site should be design.

Seismic wave propagation was conducted in time domain analysis. The seismic wave propagate from baserock to ground surface was conducted by using Computer Program NERA (Non-linear Earthquake Response Analysis, Bardet dan Tobita, 2001). Shear wave 
propagates vertically in a one-dimensional layered system, in which the soil layers are assumed to be horizontally homogeneous, infinite horizontal extent, and subjected only to horizontal motion from base-rock.

Seven input motions are considered for each period of interest that were scaled at $\mathrm{T}=0.2 \mathrm{sec}, \mathrm{T}=1 \mathrm{sec}, \mathrm{T}=2$ sec, $\mathrm{T}=5 \mathrm{sec}$, and $\mathrm{T}=10 \mathrm{sec}$, respectively.

Table 4-1 Seven input of ground motion catalog MCE and SLE

\begin{tabular}{|c|c|c|c|c|c|c|}
\hline $\begin{array}{c}\text { Period } \\
(\mathrm{sec})\end{array}$ & $\begin{array}{c}\text { Earthquake } \\
\text { Mechanism }\end{array}$ & Code Catalog & Source & Earthquake & Magnitude & $\begin{array}{c}\text { Epicentral } \\
\text { Distance }\end{array}$ \\
\hline \hline $0.2 \mathrm{sec}$ & Shallow crustal & SER270 & PEER & $\begin{array}{c}\text { Landers Earthquake, 29 June } \\
1992\end{array}$ & 7.28 & 75.20 \\
\hline $1.0 \mathrm{sec}$ & Megathrust & KAU078-N & PEER & $\begin{array}{c}\text { Chi-chi Earthquake, 20 september } \\
1999\end{array}$ & 7.62 & 160.21 \\
\hline $2.0 \mathrm{sec}$ & Megathrust & ILA051-N & PEER & $\begin{array}{c}\text { Chi-chi Earthquake, 20 september } \\
1999\end{array}$ & 7.62 & 160.21 \\
\hline \multirow{2}{*}{$5.0 \mathrm{sec}$} & Megathrust & $\begin{array}{c}\text { HKD1260309260 } \\
450 \mathrm{~W}\end{array}$ & K-NET & $\begin{array}{c}\text { Takachi-oki Earthquake, 25 } \\
\text { September 2003 }\end{array}$ & 8.00 & 174.20 \\
\cline { 2 - 8 } & Benioff & $\begin{array}{c}\text { Padang30sept20 } \\
\text { 09NS }\end{array}$ & $\begin{array}{c}\text { Rusnardi, } \\
\text { Kiyono }\end{array}$ & $\begin{array}{c}\text { Padang Earthquake, 30 } \\
\text { september 2009 }\end{array}$ & 7.60 & 81.00 \\
\hline \multirow{2}{*}{$10.0 \mathrm{sec}$} & Megathrust & $\begin{array}{c}\text { MYG0131103111 } \\
46 E W\end{array}$ & K-NET & $\begin{array}{c}\text { Tohoku Earthquake, 11 March } \\
2011\end{array}$ & 9.00 & 170.00 \\
\cline { 2 - 8 } & Benioff & TAPO78-W & PEER & $\begin{array}{c}\text { Chi-chi Earthquake, 20 september } \\
1999\end{array}$ & 7.62 & 160.21 \\
\hline
\end{tabular}

Ground response spectra design based on result of site specific response analysis for 2\% PE in 50 years and 50\% $\mathrm{PE}$ in 30 years and compared to SNI-1726-2012 are presented in Fig. 4-2 to Fig. 4-5, respectively.

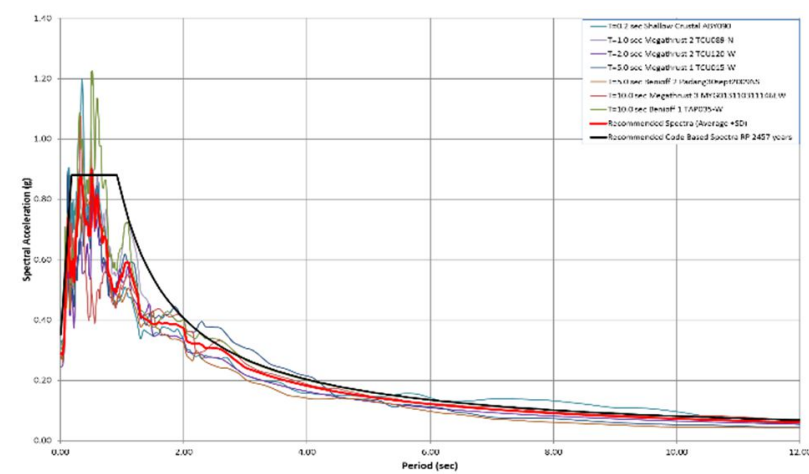

Fig. 4-2 Ground surfece Spectra for 2\% PE in 50 years

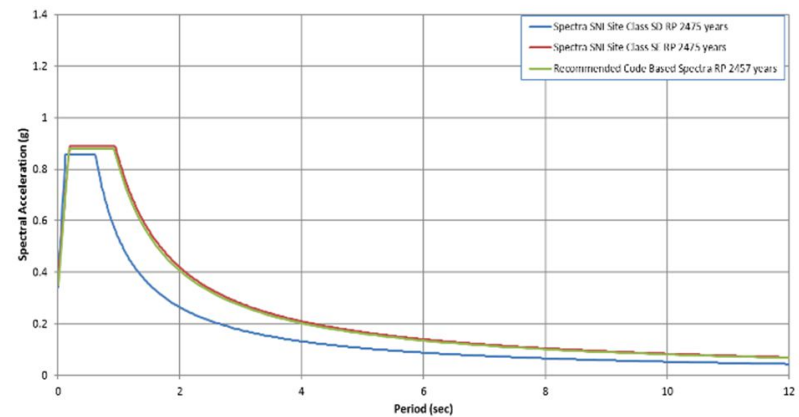

Fig. 4-3 Recommended envelope spectra 2\% PE in 50 years compare to SNI-2012 site class SE \& SD

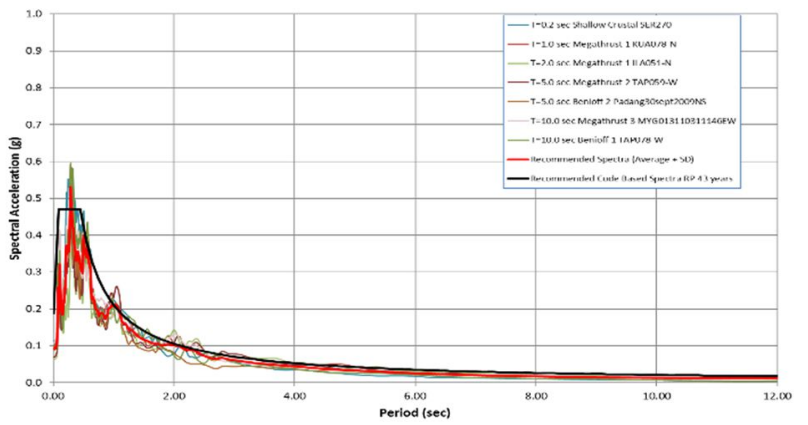

Fig. 4-4 Ground surface Spectra for 50\% PE in 30 years

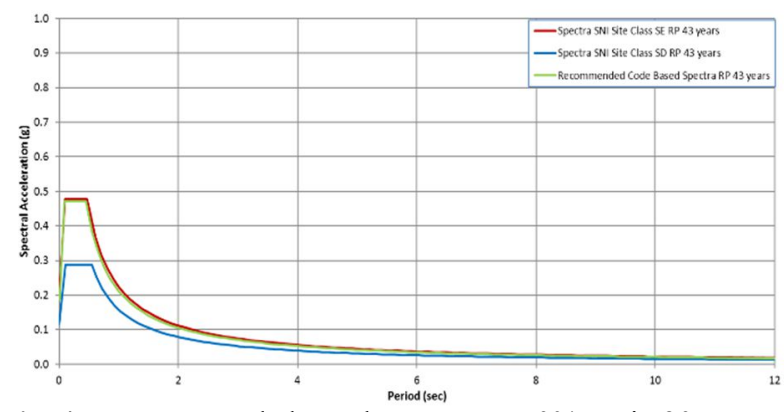

Fig. 4-5 Recommended envelope spectra 50\% PE in 30 years compare to SNI-2012 site class SE \& SD

\section{Ground Motion Generation}

In many cases, ground motion parameters alone do not adequate to describe the effects of ground shaking. For analysis of nonlinear problems such as the response of inelastic structures or the permanent deformation of an unstable slope, time histories of ground motion are required. Time histories can also be required in the development of site-specific design ground motions. Time histories that match target ground motion parameters such as peak accelerations, velocities, or spectral ordinat are required.

For generation of eleven (7) pairs of input motions for structural analysis, it is consider each pair of ground motion has a value of Square Root of the Sum of the Square (SRSS) to matched each ground motion resulted from SSRA. In this case, for particular time histories, ratio of SRSS to each direction component pair of the time histories was calculated. Next step was developed ratios, $\mathrm{K}$, at each period for the SRSS to the Target Spectrum (MCER-RP 2475 years). Then, divide both components of the recorded spectra by $\mathrm{K}$ at each period to develop modified target spectra for both components. Finally, Spectral match each recorded component (initial/original time histories) to the corresponding modified target spectrum. Example procedure for Original Time Histories TCU120 (Chi-chi Taiwan Earthquake, 20 ${ }^{\text {th }}$ September 1999) as follow:

1. Response Spectra from a pair of time histories Catalog, TCU120-N and TCU120-W

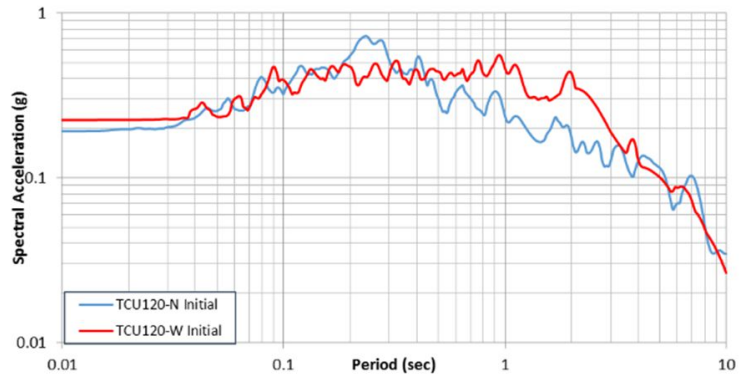

Fig. 5-1 Original Ground Motion Catalog

2. Compute Square Root of the Sum of the Square (SRSS) of the response spectra

$$
S R S S=\sqrt{S a(T i)_{T C U 120-W}{ }^{2}+S a(T i)_{T C U 120-N}{ }^{2}}
$$




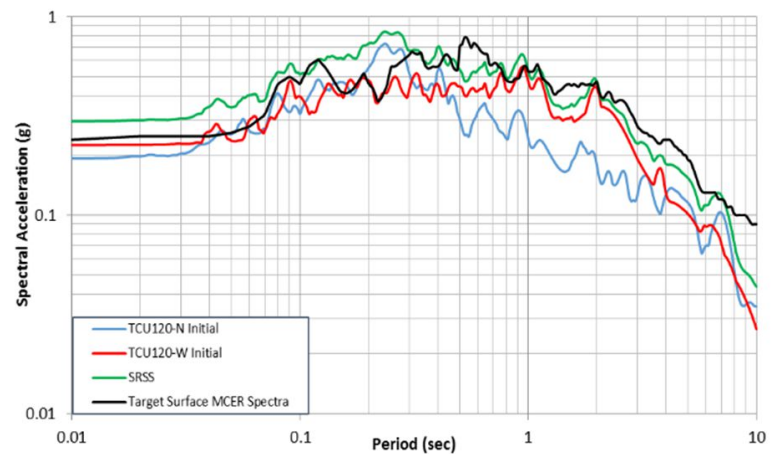

Fig. 5-2 Computed Square Root of the Sum of the Square (SRSS)

3. Find ratio, K, of SRSS with Target Surface MCER Spectra at each period with following Equation

$$
K=\frac{\text { SRSS }}{\text { Target Surface MCER }} \text {, for each period }
$$

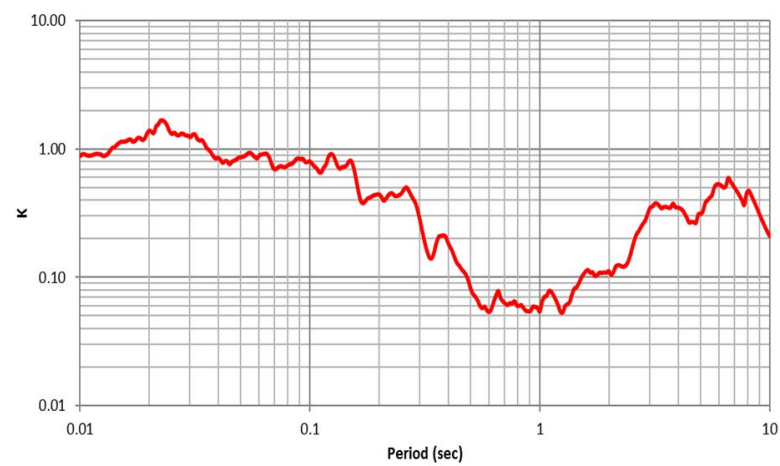

Fig. 5-3 Ratio of K

4. Each components spectra TCU120-N and TCU120-W divided by ratios K to develop TCU120-N Target and TCU120-W Target, SRSS from both component spectra will match with RP 2475 shows in Fig. below.

$$
\begin{aligned}
& \text { TCU120-WTarget }=\frac{T C U 120-W \text { Initial }}{K} \\
& \text { TCU120 }-N \text { Target }=\frac{T C U 120-N \text { Initial }}{K}
\end{aligned}
$$



Fig. 5-4 Graph spectra Target and SRSS

5. Conducted spectral match to TCU120-N Target and TCU120-W Target from TCU120-N Initial to TCU120-W Initial

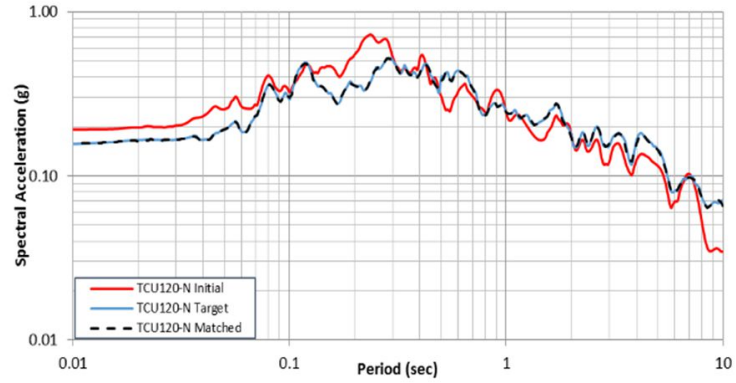

Fig. 5-5 Initial to Target spectra

6. SRSS of the Matched Time Histories

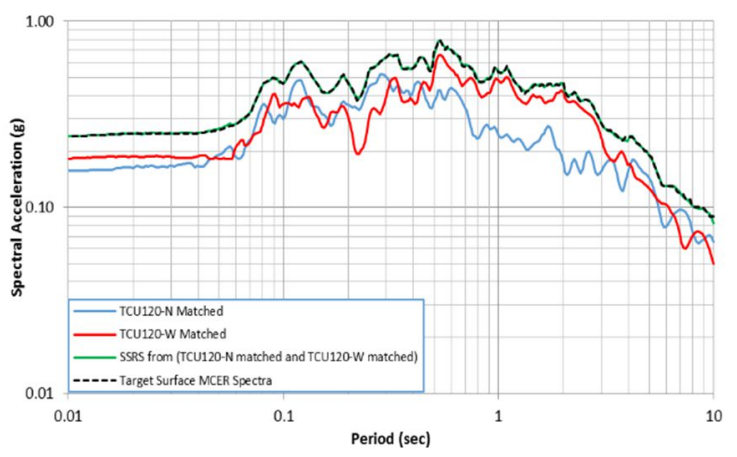

Fig. 5-6 SRSS of Matched Time Histories/input motion
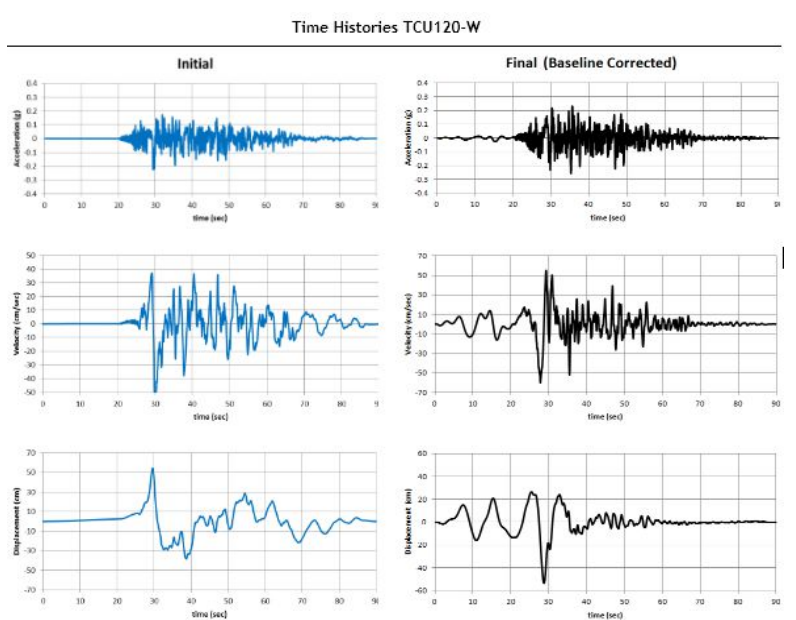

Fig. 5-7 Time history ground motion

FEMA P-1050-1/2015 state that, for nonlinear responsehistory analysis, design earthquake and $\mathrm{MCE}_{\mathrm{R}}$ groundmotion suites shall each consist of not less than sevenpairs of horizontal acceleration components. Selected and scaled from individual recorded events having magnitudes, fault distance and source mechanisms that are consistent with those that control the design earthquake and MCER events. Spectral matching is permitted to scale the ground motions. For both the design earthquake and the MCER suites:

(a) each pair of motions shall be scaled such that in the period range from $0.2 \mathrm{~T} 1 \mathrm{D}$ to $1.25 \mathrm{~T} 1 \mathrm{M}$, the average of the SRSS spectra from all horizontal component pairs does not fall below the corresponding ordinate of the response spectra used in the design.

(b) each pair of motions shall be scaled such that in the period range from $0.2 \mathrm{~T} 1 \mathrm{D}$ to $1.25 \mathrm{~T} 1 \mathrm{M}$, the response 
spectrum of one component of the pair is at least $90 \%$ of the corresponding ordinate of the response spectrum used in the design.

In this case of ground-motion generation, each pair of ground-motions has been scaled adopting scaling-factor in such away that spectral acceleration of SRSS of each pair within the spectral period of (0.2-10) second does not less than $90 \%$ of that of the recommended spectral value. This is shown in Fig. 4.2 and Fig. 4.4 where the seven SRSS spectra are within the range not fall below the recommended spectra (red spectra line).

\section{Concluding Remarks}

Site-specific response analysis (SSRA) and generation of pairs of ground-motions time-history has been conducted for a proposed high-rise building in Jakarta. The SSRA has been integrated with the probabilistic seismic hazard analysis (PSHA) adopting seismic source zones, seismic parameters, and ground-motion predictive equations in accordance with the 2010 Indonesian seismic hazard map for Jakarta site. The PSHA was integrated with the SSRA and pairs of ground motions generation to identify the dominant sources that controlled hazard of the site through de-aggregation analysis, associated with level of hazards and spectral periods of interest. The analysis has identified subduction Megathrust and Beniof (Deep Background) sources as controlling earthquakes within the range of structure periods, for the MCE and SLE level, respectively.

The controlling earthquakes has been generated at reference base-rock with scaling to $\mathrm{MCE}_{\mathrm{R}}$ and SLE level to controlling spectral periods adopting conditional mean spectra. Wave propagation analyses of the generated baserock ground-motions has resulted in recommended ground-surface response spectra. Furthermore, 7-pairs of ground-surface motions have been generated as an integrated process of the propagated base-rock ground motions. The pairs of ground motions have been generated to match the recommended spectra in accordance with the FEMA-1050-2015.

Procedures of SSRA and pairs of ground-motions elaborated in this paper could be adopted for other sites. For pairs of ground-motion generation with Code-Based spectra as the target spectra, CMS spectra at ground surface scaled and modified to several periods that also meet the FEMA-1050-2015 or other codes requirement could be conducted.

The author thankful to PT Wiratman and Associates and PT Putragaya Wahana for data support and collaboration. Numerous input by Dr. Ramin Goleshorki from Langan International is also appreciated.

\section{References}

1. American Society of Civil Engineers Standards, ASCE SEI-7-10, Minimum Design Loads for
Buildings and Other Structures, Sructural Engineering Institute ASCE, Virginia, USA, (2010).

2. Bardet J.P., Tobita T., "NERA, A Computer Program for Nonlinear Earthquake Site Response Analyses of layered Soil Deposits", University of Southern California, (2001).

3. Frankel, A. D. Mapping Seismic Hazard in the Central and Eastern United States. Seismological Research Letters. 66:4. 8-21.P, (1995).

4. Indonesian Seismic Building Codes, SNI-03-1726, Indonesian Department of Public Work, (2002).

5. Irsyam, M., Sengara, IW., Aldiamar, F., Widiyantoro, S., Triyoso, W., Natawijaya, D.H., Kertapati, E., Meilano, I., Asrurifak, M., Ridwan, M., Suhardjono,: Development of Seismic Hazards Map of Indonesia for Revision of SNI 03-1726-2002, (2010), A Summary Report submitted to Australia-Indonesia Facility for Disaster Reduction (AIFDR) and Badan Nasional Penanggulangan Bencana (BNPB), Institute for Research and Community Services, Institut Teknologi Bandung, (2010).

6. Luco, N., Ellington, B.R., Hamburger, R.O., Hooper, J.D., and Kimball, J.K., "Risk-Targeted versus current Seismic Design Maps for Conterminous United States", SEAOC 2007 Convention Proceedings, (2007).

7. McGuire, R.K., Seismic Hazard and Risk Analysis, Earthquake Engineering Research Institute (EERI) Publication No. MNO-10, Oakland, California, USA, (2004).

8. NEHRP Recommended Seismic Provisions for New Buildings and Other Structures, FEMA P-750/2009 Edition, Building Seismic Safety Council, Washington D.C.

9. NEHRP Recommended Seismic Provisions for New Buildings and Other Structures Volume I: Part 1 Provisions, Part 2 Commentary FEMA P-1050-1/2015 Edition, Building Seismic Safety Council, Washington D.C.

10. Newcomb, K.R., McCann, W.R. "Seismic History and Seismotectonic of the Sunda Arc", Journal of Geophysical Research, Vol. 92, No. B1, 421-439, (1987).

11. Pacific Earthquake Engineering Research Center. Tall Building Initiative Guidelines for Performance Based Seismic Design of Tall Buildings. Report N0. 2010/5. (2010).

12. Risk Engineering, "EZ-FRISK (Software for in-depth Seismic Hazard Analysis) User's Manual”, Risk Engineering Inc., Golden, Colorado, USA. (2011).

13. Sengara, IW., Merati, G.W., Widiyantoro, S., Natawidjaja, D.H., Triyoso, W., Meilano, I., Kertapati, E., Sumiartha, P., Hendarto, Final Report on Integrated Probabilistic Seismic Hazard Investigation of Indonesia (Sumatra, Java, and Nusa Tenggara)- in Indonesian, prepared for Ministry of Research and Technology, Center for Disaster Mitigation-Institut Teknologi Bandung, Indonesia. (2009).

14. Sengara, IW., "Development of Earthquake Scenario for Three Different Sites within City of Jakarta", Earthquake Geotechnical Engineering Satellite 
Conference XVIIth International Conference on Soil Mechanics \& Geotechnical Engineering, Alexandria, Egypt, (2009).

15. Sengara, IW., and Jayasaputra, U., Study of Empirical Correlations to Estimate Shear Wave Velocity based on MASW, Seismic Downhole, and Soil Investigation Data, Research Report, Geotechnical Engineering Laboratory, Inter University Center for Engineering Science, Institut Teknologi Bandung. (2010).

16. Sengara, IW., Sumiartha, P., Handayani, G., and Yulman, M.A., "Report on Probabilistic Seismic Hazard and Site-Specifiv Response Analysis to Derive Seismic Design Criteria for Signature Tower Jakarta, a Report submitted to PT. Grahamas Adisentosa, PT Georeka Indonesia. (2012).

17. Stewart, J.P., Archuleta, R.J., and Power, M.S., Earthquake Spectra, The Professional Journal of the
Earthquake Engineering Research Institute, Special Issue on the Next Generation Attenuation Project, Volume 24, Number 1, (2008).

18. Youngs, R. R., Chiou, S. J., Silva, W. J., Humphrey, J. R., "Strong Ground Motion Attenuation Relationship for Subduction Zone Earthquake", Bulletin of Seismological Society of America Vol. 68, No. 1. (1997).

19. Zhao, John X., Jian Zhang, Akihiro Asano, Yuki Ohno, Taishi Oouchi, Toshimasa Takahashi, Hiroshi Ogawa, Koijiro Irikura, Hong K. Thio, Paul G. Sommerville, Yasuhiro Fukushima, and Yoshimitsu Fukushima. Attenuation Relations of Strong ground Motion in Japan Using Site Classification Based on Predominant Period. Bulletin of the Seismological Society of America 96: 3, 898-913. (2006). 